Eur. J. Clin. Chem. Clin. Biochem.

Vol. 32, 1994, pp. 293-299

C 1994 Walter de Gruyter \& Co.

Berlin · New York

\title{
Determination of Chondroitin-6-Sulphate by a Competitive Enzyme Immunoassay Using a Biotinylated Antigen
}

\author{
By Heike Kähnert ${ }^{1}$, T. Brinkmann ${ }^{1}, N$. Gässler ${ }^{2}$ and K. Kleesiek ${ }^{1}$
}

1 Institut für Laboratoriums- und Transfusionsmedizin, Herz- und Diabeteszentrum Nordrhein-Westfalen, Universitätsklinik der Ruhr-Universität Bochum, Bad Oeynhausen, Germany

2 Institut für Klinische Chemie II der Medizinischen Hochschule Hannover, Zentrallabor im Oststadtkrankenhaus, Hannover; Germany

(Received July 3/September 13, 1993)

Dedicated to Prof. Dr. Dr. Helmut Greiling on the occasion of his 65th birthday

Summary: A competitive enzyme immunoassay was developed to determine chondroitin-6-sulphate in body fluids and cell cultures. The assay uses a monoclonal anti-chondroitin-6-sulphate antibody, immobilised to microtitre plates, and it involves a competitive binding reaction between chondroitin-6-sulphate in the samples and the biotinylated antigen.

This assay enables the quantification of chondroitin-6-sulphate in the low concentration range of $16-120 \mu \mathrm{g} / \mathrm{l}$. The intra-assay and inter-assay coefficients of variation are below $6.5 \%$ and $9.0 \%$, respectively. More than $90 \%$ of chondroitin-6-sulphate was recovered when added to $0.1 \mathrm{~mol} / 1$ phosphate-buffered saline, an albumin solution ( $40 \mathrm{~g} / \mathrm{l}$ in phosphate-buffered saline) and cell culture medium (containing $100 \mathrm{ml} / \mathrm{l}$ foetal calf serum).

Chondroitin-6-sulphate was also determined in sera of healthy male $(n=90)$ and female $(n=90)$ blood donors. The normal range was $55-169 \mu \mathrm{g} / \mathrm{l}$. In men the mean value was estimated at $102.2 \pm 37.1 \mu \mathrm{g} / \mathrm{l}$ and in women at $98.7 \pm 26.4 \mu \mathrm{g} / \mathrm{l}$. No age or sex dependence was observed.

The urine excretion of chondroitin-6-sulphate in men $(\mathrm{n}=16)$ was $44.5 \pm 21.1 \mathrm{mg} / \mathrm{kg}$ creatinine (mean \pm standard deviation) and in females $(\underline{n}=10) 53.5 \pm 21.3 \mathrm{mg} / \mathrm{kg}$ creatinine. The clearance rate in men was $0.41 \pm 0.22$ $\mathrm{ml} \times \min ^{-1}$ and in women $0.38 \pm 0.15 \mathrm{ml} \times \mathrm{min}^{-1}$. No sex dependence was found.

Furthermore, the enzyme immunoassay was modified to measure the specific incorporation of a radioactively labelled precursor $\left(\left[{ }^{14} \mathrm{C}\right]\right.$ galactosamine) into chondroitin-6-sulphate. This modification rapidly gives information on the cellular glycosaminoglycan synthesis in cell culture. Using this method our experiments with cultivated human chondrocytes showed that the synthesis of chondroitin-6-sulphate decreased in the presence of interleukin- $1 \alpha$ (60.0\% less), tumour necrosis factor $\alpha(64.4 \%), \gamma$-interferon (21.6\%) and lipopolysaccharide $(53.4 \%)$.

\section{Introduction}

Chondroitin sulphate consists of repeated disaccharide units containing $\mathrm{N}$-acetyl- $D$-galactosamine and $D$-glucuronic acid. This glycosaminoglycan is sulphated either on the C4 or C6 position of the amino sugar (1) and, attached to a core protein to form proteoglycans. The macromolecule is synthesised in the Golgi apparatus, transported to the cell surface and secreted into the extracellular space (2). Chondroitin sulphate is a major and ubiquitous component of the extracellular matrix of connective tissues (1). Several methods for the determi- 
nation of chondroitin sulphate have been described. These techniques use enzymatic digestion, precipitation and chromatographic methods, especially high performance liquid chromatography $(3,4)$.

Methods have been reported recently, which use specific antibodies against different components of proteoglycans (e. g. keratan sulphate, dermatan sulphate) $(5-8)$. So far, an enzyme immunoassay of chondroitin sulphate has not been described. The assay described here uses a monoclonal anti-chondroitin-6-sulphate antibody (9) and involves a competitive binding reaction between chondroitin-6-sulphate in the sample and biotinylated chondroitin-4-sulphate as labelled antigen. This enzyme immunoassay enables the determination of chondroitin6-sulphate in serum, urine and cell culture medium.

\section{Materials and Methods}

\section{Materials}

Bovine serum albumin was obtained from Merck, Darmstadt. Tween 20, o-phenylenediamine, 1-ethyl-3-(3-dimethylaminopropyl)-carbodiimide, monoclonal anti-chondroitin-6-sulphate antibody (CS 56), adipic acid dihydrazide and $\mathrm{N}$-hydroxysuccinimidobiotin were purchased from Sigma, Deisendorf. Streptavidincoupled horse radish peroxidase ${ }^{1}$ ) was from Boehringer, Mannheim, and chondroitinase $\mathrm{ABC}^{\mathrm{l}}$ ) from Seikagaku, Tokyo Maxisorb immunoplates were obtained from Nunc, Wiesbaden. Chondroitin-6-sulphate and chondroitin-4-sulphate were obtained from Medac, Hamburg and from Sigma, Deisendorf. All chemicals used were of analytical grade or the highest commercially available grade.

\section{Methods}

\section{Preparation of biotinylated antigen}

Chondroitin sulphate $(500 \mathrm{mg})$ was dissolved in $3 \mathrm{ml}$ adipic acid dihydrazide ( $40 \mathrm{~g} / \mathrm{l}, \mathrm{pH} 4.75)$ and shaken for $30 \mathrm{~min}$ at room temperature. The solution was incubated for 1 hour at $4{ }^{\circ} \mathrm{C}$ with 1 ethyl-3-(3-dimethylaminopropyl)-carbodiimide in a ratio of $1: 100$ by vol. After dialysis, $2 \mathrm{~g} / \mathrm{l}$ N-hydroxysuccinimidobiotin were added and the solution was incubated for 2 hours. After further dialysis the biotinylated antigen was stored at $-20^{\circ} \mathrm{C}$.

\section{Enzyme immunoassay}

The wells of a plastic microtitre plate were coated overnight at $4{ }^{\circ} \mathrm{C}$ with the anti-chondroitin-6-sulphate antibody $(50 \mu \mathrm{l} /$ well, $1: 2000$ dilution of the ascitic fluid in $0.1 \mathrm{~mol} / 1$ phosphate-buffered saline $\left(8.0 \mathrm{~g} / \mathrm{l} \mathrm{NaCl}, 0.2 \mathrm{~g} / 1 \mathrm{KCl}, 0.2 \mathrm{~g} / 1 \mathrm{KH}_{2} \mathrm{PO}_{4}, 1.1 \mathrm{~g} / 1 \mathrm{~K}_{2} \mathrm{HPO}_{4}, \mathrm{pH}\right.$ 7.4)) overnight at $4{ }^{\circ} \mathrm{C}$. The coating solution was removed and the plates were washed three times with phosphate-buffered saline and blocked with bovine serum albumin $(2 \mathrm{~g} / \mathrm{l}$ phosphate-buffered saline, $100 \mu \mathrm{l} /$ well) at room temperature for 1 hour. Samples (50 $\mu \mathrm{l} /$ well) or chondroitin-6-sulphate standard diluted in phosphatebuffered saline-Tween were added. After incubation for two hours at $4{ }^{\circ} \mathrm{C}, 50 \mu \mathrm{l}$ of the biotinylated antigen were added to each well for 1 hour at $4^{\circ} \mathrm{C}$. The wells were washed three times with phosphate-buffered saline-Tween, then $50 \mu l$ streptavidin horse-radish

\footnotetext{
1) Enzymes:

Chondroitinase ABC EC 4.2.2.4

Horse-radish peroxidase EC 1.11.1.7
}

peroxidase $(60 \mathrm{U} / \mathrm{l})$ were added and the solution was incubated for one hour at $4^{\circ} \mathrm{C}$. The wells were washed with phosphate-buffered saline and incubated with $50 \mu \mathrm{l}$ of freshly prepared 0 -phenylenediamine $(60 \mathrm{~g} / \mathrm{l})$ at room temperature for 45 minutes. The enzymatic colour development was stopped by adding $50 \mu \mathrm{l} 0.5 \mathrm{~mol} / \mathrm{l}$ sulphuric acid and the absorbance was measured at $492 \mathrm{~nm}$ with a Behring microtitre enzyme immunoassay reader.

$\therefore$

\section{Analysis of chondroitin sulphates by high performance liquid chromatography}

The chondroitin-6-sulphate used as standard and the chondroitin4-sulphate used as biotinylated antigen were analysed by high performance liquid chromatography to determine the composition of unsaturated chondroitin-sulphate disaccharide. The HPLC analysis of the disaccharide was carried out according to a modified method of $E$. Gurr et al. (4).

\section{Modification of the enzyme immunoassay to determine the chondroitin-6-sulphate synthesis of cultured cells by monitoring $\left[{ }^{14} \mathrm{C}\right.$ galactosamine incorporation}

The concentration of ${ }^{14} \mathrm{C}$-labelled chondroitin-6-sulphate in the medium of cultured human chondrocytes was measured by the enzyme immunoassay as described above. In a parallel experiment, after the competitive binding reaction, the microtitre wells were incubated with trypsin $(3 \mathrm{~g} / \mathrm{l})$ to detach the ${ }^{14} \mathrm{C}$-labelled antigen/ antibody complex from the microtitre plates. This enzymatic digestion enabled quantification of radioactivity in a scintillation well. This method will be published elsewhere (10).

Recovery, precision and detection limit of the enzyme immunoassay

The accuracy of the enzyme immunoassay was investigated by adding a constant amount of chondroitin-6-sulphate $(60 \mathrm{mg})$ to 0.1 $\mathrm{mol} / \mathrm{l}$ phosphate-buffered saline, to an albumin solution $(40 \mathrm{~g} / \mathrm{l}$ in phosphate-buffered saline), and to a cell culture medium (containing $100 \mathrm{ml} / 1$ foetal calf serum). The concentration of chondroitin6-sulphate was determined before and after addition, and the recovery was calculated.

Different concentrations of chondroitin- 6 -sulphate $(20,80$ and 120 $\mu \mathrm{g} / \mathrm{l})$ were used to determine the inter-assay $(n=70)$ and intraassay $(n=15)$ variation coefficients.

To determine the detection limit of the enzyme immunoassay, chondroitin-6-sulphate was added in concentrations of $0,4,8$ and $16 \mu \mathrm{g} / \mathrm{l}$ to $0.1 \mathrm{~mol} / \mathrm{l}$ phosphate-buffered saline and to an albumin solution (40 $\mathrm{g} / 1$ in phosphate-buffered saline). The low $3 \mathrm{~s}$-limit $(\bar{x}-3 s)$ of the chondroitin-6-sulphate-free samples was calculated after a series of 48 determinations. The lowest chondroitin-6-sulphate concentration (mean of 48 determinations), which was significantly different from this calculated value, was defined as the detection limit.

\section{Sample preparation}

1. Venous blood was obtained from healthy male $(n=90)$ and female $(n=90)$ donors aged 18-65. After clotting, followed by centrifugation for 10 minutes at $4000 \mathrm{~min}^{-1}$, the serum was frozen and stored until use.

2. The urine collection started in the morning by rejecting the previous night urine and finished after 24 hours by including the subsequent night urine. This urine collection avoids any influence of circadian rhythm effects on the chondroitin-6-sulphate determination. Urine from 16 healthy male and 10 healthy female volunteers were tested. 
3. Human chondrocytes were precultivated as a monolayer for 24 hours in Dulbecco's modified Eagles medium supplemented with heat-inactivated foetal calf serum $(50 \mathrm{ml} / \mathrm{l})$, antibiotics and mediators. After 24 hours, fresh medium containing the mediators and $\left[{ }^{14} \mathrm{C}\right]$ glucosamine hydrochloride $56 \mathrm{MBq} / \mathrm{l}$ was added. The culture media were collected and the chondroitin-6-sulphate concentration and specific incorporation rates were determined. The following mediator concentrations were used: interleukin- $1 \alpha\left(10^{4} \mathrm{U} / \mathrm{l}\right)$, tumour necrosis factor $\alpha(100 \mu \mathrm{g} / \mathrm{l}), \gamma$-interferon $\left(2 \cdot 10^{5} \mathrm{U} / \mathrm{l}\right)$ and lipopolysaccharide $(10 \mu \mathrm{g} / \mathrm{l})$. The mediator concentrations were chosen according to dose-response studies in which the efficacy of these concentrations was demonstrated (10).

\section{Statistical analysis}

The significance of the mean value difference and the age and sex dependence of chondroitin-6-sulphate were calculated using Student's t test and linear correlation analysis, respectively.

\section{Results}

Analysis of chondroitin-6-sulphate and chondroitin-4-sulphate by high performance liquid chromatography

The chondroitin-6-sulphate used as a standard contained $78.3 \%$ chondroitin- 6 -sulphate and $21.7 \%$ chondroitin-4sulphate. The dose response curve of the enzyme immunoassay was established on the basis of the amount of chondroitin-6-sulphate in the standard. The composition of chondroitin-4-sulphate was $89.5 \%$ chondroitin4-sulphate, $4.5 \%$ chondroitin-6-sulphate and $6 \%$ nonsulphated chondroitin (chondroitin-0-sulphate).

\section{Biotinylation of antigens}

The binding affinity of the biotinylated chondroitin-6sulphate and biotinylated chondroitin-4-sulphate to the monoclonal antibody was investigated. The antigenicity of chondroitin-6-sulphate was considerably reduced after biotinylation (fig. 1). Despite several modifications of the biotinylating reaction it was not possible to increase the antigenicity of biotinylated chondroitin-6-sulphate. However, the antigenicity of chondroitin-4-sulphate was not influenced by biotinylation, so this was used as the competitive antigen in an optimal concentration of $100 \mathrm{mg} / 1$.

\section{Dose response curve of the enzyme immunoassay}

The dose response curve of the enzyme immunoassay was obtained by using the biotinylated chondroitin-4sulphate as competitive antigen (fig. 2). Corresponding standard curves were obtained using $0.1 \mathrm{~mol} / \mathrm{l}$ phosphate-buffered saline and albumin $(40 \mathrm{~g} / 1$ in $0.1 \mathrm{~mol} / \mathrm{l}$ phosphate-buffered saline). In addition, the standard curve of chondroitin-6-sulphate in foetal calf serum (100

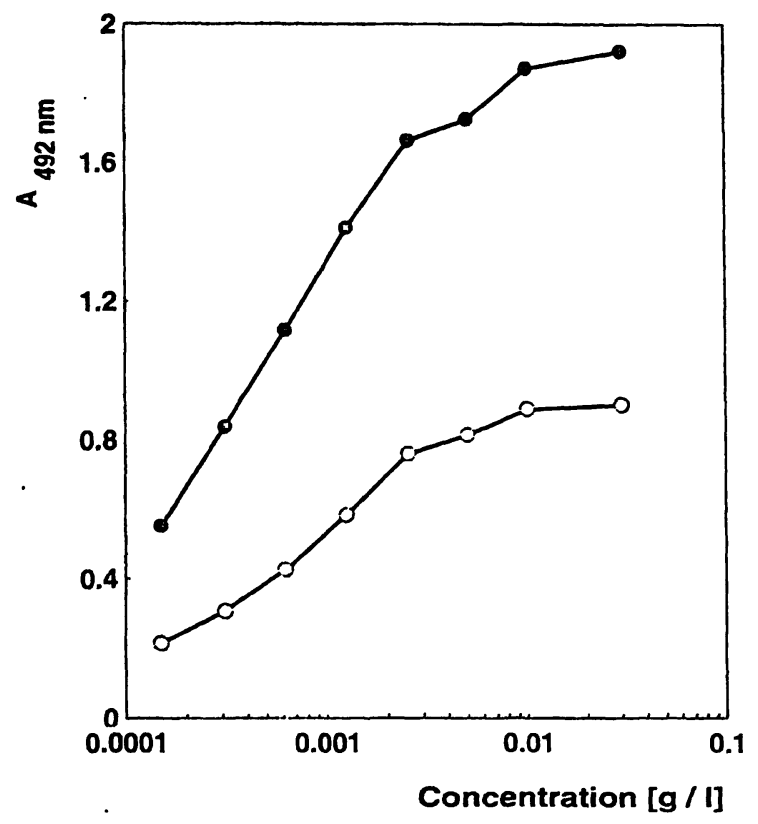

Fig. 1 Binding of biotinylated chondroitin-6-sulphate $(0-0)$ and biotinylated chondroitin-4-sulphate $(\mathbf{0}-\boldsymbol{\theta})$ to the monoclonal antichondroitin-6-sulphate antibody. The labelled chondroitin sulphates were added in different concentrations to the anti-chondroitin-6sulphate antibody. The antigen-antibody complex was incubated with streptavidin horse-radish peroxidase and the absorbance at $492 \mathrm{~nm}$ was measured after substrate addition.

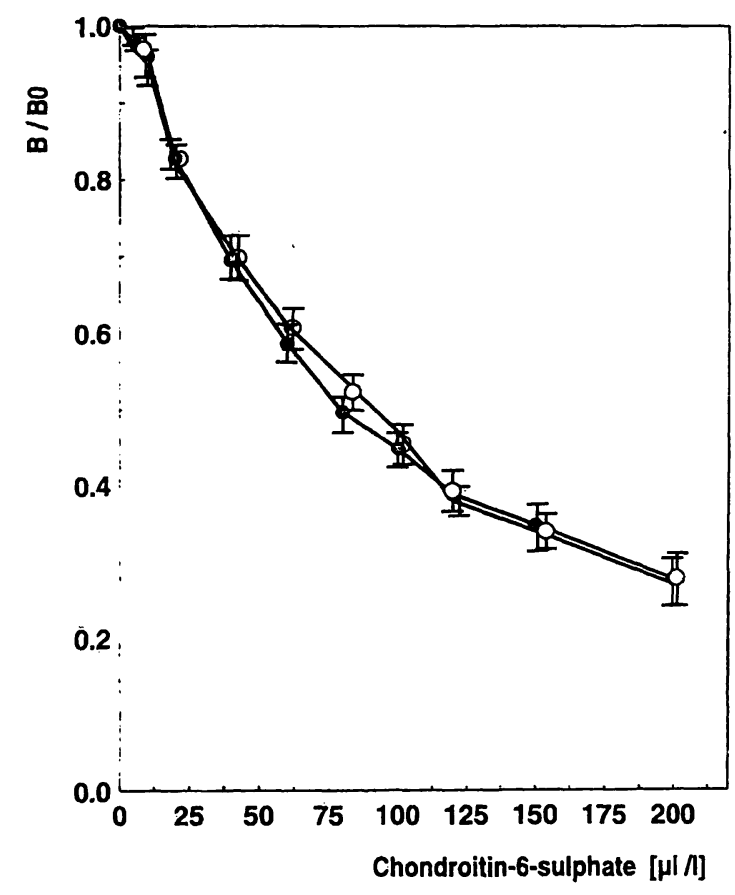

Fig. 2 Dose-response curve of the chondroitin-6-sulphate enzyme immunoassay in different matrices: $0.1 \mathrm{~mol} / \mathrm{l}$ phosphate-buffered saline $(0-0)$ and albumin $(40 \mathrm{~g} / \mathrm{l})(\bullet-\bullet)$. Mean value and standard deviation of 48 determinations are given.

$\mathrm{ml} / \mathrm{l})$ showed a similar course. The linearity of the dose response curve was found at a concentration of 16-120 $\mu \mathrm{g} / \mathrm{l}$. Matrix effects were observed only at a chondroitin6-sulphate concentration of $80 \mu \mathrm{g} / \mathrm{l}$. The difference between the phosphate-buffered saline standard curve and 
the albumin standard curve was $8 \%$. However, the difference was within the standard deviation. At all other concentrations the differences were less than $5 \%$.

\section{Cross-reactivity of the enzyme immunoassay with other glycosaminoglycans}

Cross-reactivity is defined as $50 \%$ inhibition of binding of glycosaminoglycans to the monoclonal antibody. The $50 \%$ inhibition point of chondroitin-6-sulphate was found at $27 \mu \mathrm{g} / \mathrm{l}$. The concentration of chondroitin-4sulphate required for $50 \%$ inhibition was $112 \mathrm{~g} / \mathrm{l}$, i.e. about 4000 times greater than that required for the equivalent inhibition by chondroitin- 6 -sulphate. The cross-reaction of other glycosaminoglycans was considerably outside the linear range of chondroitin-6-sulphate (fig. 3). The concentrations of these glycosaminoglycans causing $50 \%$ inhibition were: dermatan sulphate $1 \mathrm{~g} / \mathrm{l}$, keratan sulphate $>1 \mathrm{~g} / \mathrm{l}$, hyaluronan $>5 \mathrm{~g} / \mathrm{l}$, and heparin $>10 \mathrm{~g} / \mathrm{l}$.

Precision, recovery and detection limit of the chondroitin-6-sulphate immunoassay

The inter-assay and intra-assay variation coefficients are less than $9.0 \%$ and $6.5 \%$, respectively (fig. 4 ). The recovery of chondroitin-6-sulphate was in the range of $87.5 \%-109.6 \%$ (tab. 1). The detection limit was 16 $\mu \mathrm{g} / \mathrm{l}$ (tab. 2).

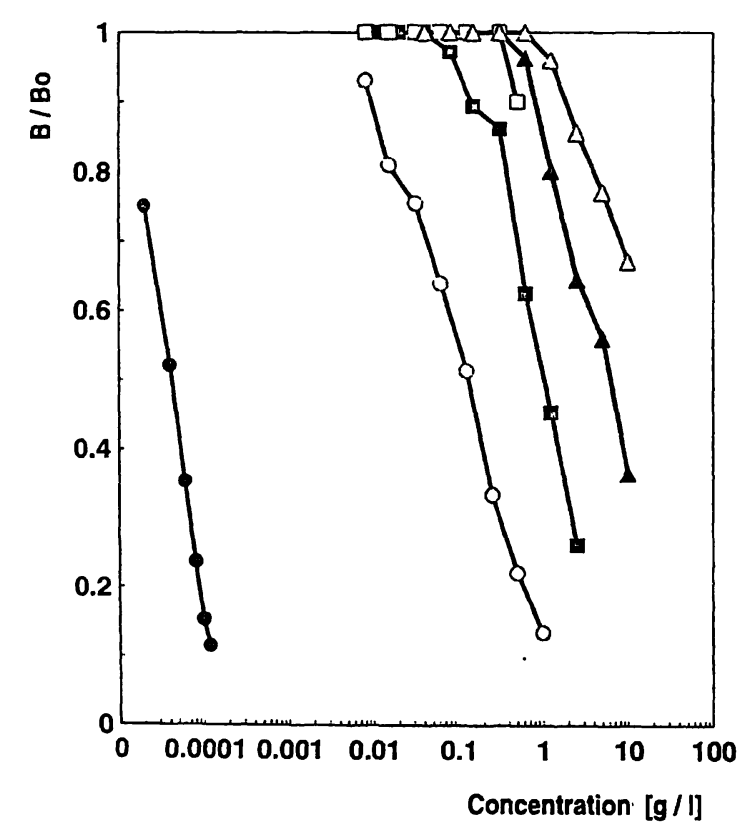

Fig. 3 Dose-response curves of the monoclonal anti-chondroitin6-sulphate antibody with different glycosaminoglycans. The crossreactivities defined as the glycosaminoglycan concentration at $50 \%$ inhibition were calculated: chondroitin-6-sulphate $(-0): 27 \mu \mathrm{g} / \mathrm{l}$; chondroitin-4-sulphate $(0-0): 112 \mathrm{mg} / \mathrm{l}$; dermatan sulphate

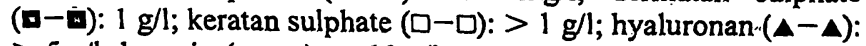
$>5 \mathrm{~g} / \mathrm{l}$; heparin $(\Delta-\Delta):>10 \mathrm{~g} / \mathrm{l}$.

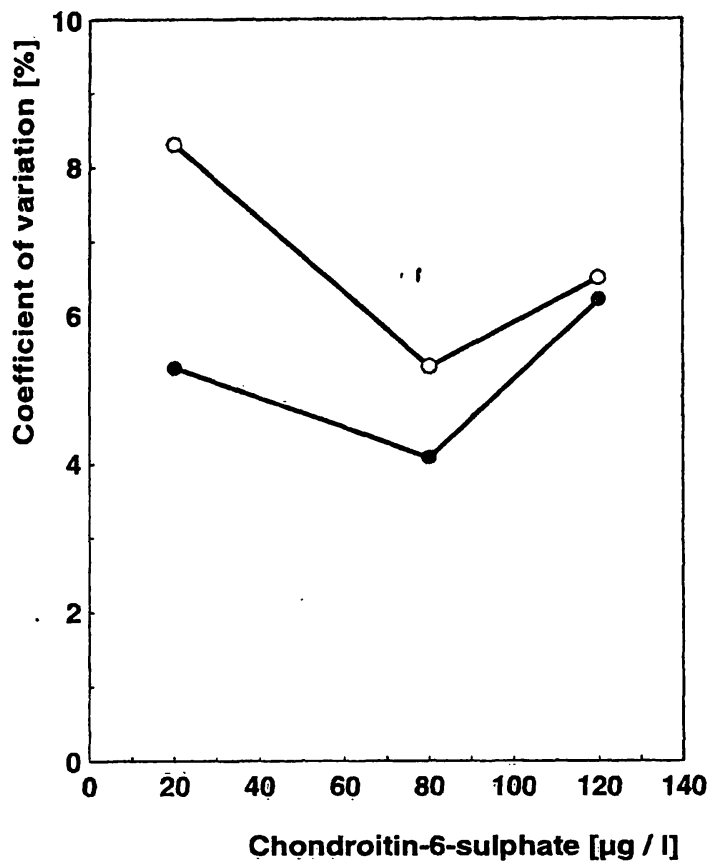

Fig. 4 Imprecision of the enzyme immunoassay. The intra-assay $(n=15)(0-0)$ and inter-assay $(n=70)(0-0)$ variation coefficients of different chondroitin-6-sulphate concentrations are given.

Tab. 1 Determination of chondroitin=6-sulphate in the presence of different matrices and recovery of exogenously added chondroitin-6-sulphate. The experiments were carried out in quadruplicate. Mean values $(\overline{\mathrm{x}})$ and standard deviations (s) are given.

\begin{tabular}{|c|c|c|c|}
\hline Matrix & $\begin{array}{l}\text { No addition } \\
\text { of } \\
\text { chondroitin- } \\
6 \text {-sulphate } \\
\text { [ } \mu \mathrm{g} / 1]\end{array}$ & $\begin{array}{l}\text { Addition of } \\
60 \mu \mathrm{g} / 1 \\
\text { chondroitin- } \\
6 \text {-sulphate } \\
{[\mu \mathrm{g} / \mathrm{l}]}\end{array}$ & Recovery \\
\hline $\begin{array}{l}\text { Phosphate-buffered } \\
\text { saline }[0.1 \mathrm{~mol} / 1]\end{array}$ & $\begin{array}{l}\text { not } \\
\text { detectable }\end{array}$ & $55.8 \pm 2.2$ & 96.3 \\
\hline $\begin{array}{l}\text { Foetal calf serum } \\
{[100 \mathrm{ml} / 1]}\end{array}$ & $68 \pm 2.1$ & $121.3 \pm 2.9$ & 94.7 \\
\hline Albumin $[40 \mathrm{~g} / 1]$ & $\begin{array}{l}\text { not } \\
\text { detectable }\end{array}$ & $65.7 \pm 2.2$ & 109.6 \\
\hline $\begin{array}{l}\text { Culture medium of } \\
\text { human fibroblast }\end{array}$ & $600 \pm 1.9 .3$ & $577.5 \pm 22$ & 87.5 \\
\hline
\end{tabular}

\section{Concentration of chondroitin-6-sulphate in blood serum}

The normal range of chondroitin-6-sulphate in blood serum was $55-169 \mu \mathrm{g} / \mathrm{l}$. In the serứm of healthy males the mean chondroitin-6-sulphate concentration was 101 $\mu \mathrm{g} / 1$ (95\% range: $56-169 \mu \mathrm{g} / \mathrm{l})$ and in females $99 \mu \mathrm{g} / \mathrm{1}$ (95\% range: $61-150 \mu \mathrm{g} / \mathrm{l})$. No sex or age dependence wạs found (fig. 5): 
Tab. 2 Evaluation of the detection limit of the enzyme immunoassay. The absorbance of the enzyme immunoassay was measured using samples with and without small amounts of chondroitin-6sulphate in $0.1 \mathrm{~mol} / \mathrm{l}$ phosphate-buffered saline and in albumin $(40 \mathrm{~g} / \mathrm{l})$. Mean values $(\mathrm{x})$ and standard deviations (s) are given. The low $3 \mathrm{~s}$-limit ( $\mathrm{x}-3 \mathrm{~s})$ of a chondroitin-6-sulphate-free sample was calculated after a series of 48 determinations. The lowest chondroitin-6-sulphate concentration (mean of 48 determinations), which was significantly different from this calculated value, was defined as the detection limit $(16 \mu \mathrm{g} / \mathrm{l})$.

\begin{tabular}{llll}
\hline Chondroitin- & Absorbance & Absorbance \\
6-sulphate & at $492 \mathrm{~nm}$ & at $492 \mathrm{~nm}$ \\
{$[\mu \mathrm{g} / 1]$} & $\mathrm{x}$ & $\mathrm{s}$ & $\mathrm{x}-3 \mathrm{~s}$ \\
\hline
\end{tabular}

\begin{tabular}{rlcc} 
& \multicolumn{3}{l}{ Matrix: Phosphate-buffered saline } \\
\hline 0 & 1.35 & & \\
4 & 1.33 & 0.031 & 1.26 \\
8 & 1.29 & & \\
16 & 1.16 & & \\
\hline
\end{tabular}

\begin{tabular}{rlll}
\multicolumn{4}{c}{ Matrix: Albumin } \\
\hline 0 & 1.41 & & \\
4 & 1.39 & 0.032 & 1.29 \\
8 & 1.37 & & \\
16 & 1.18 & & \\
\hline
\end{tabular}

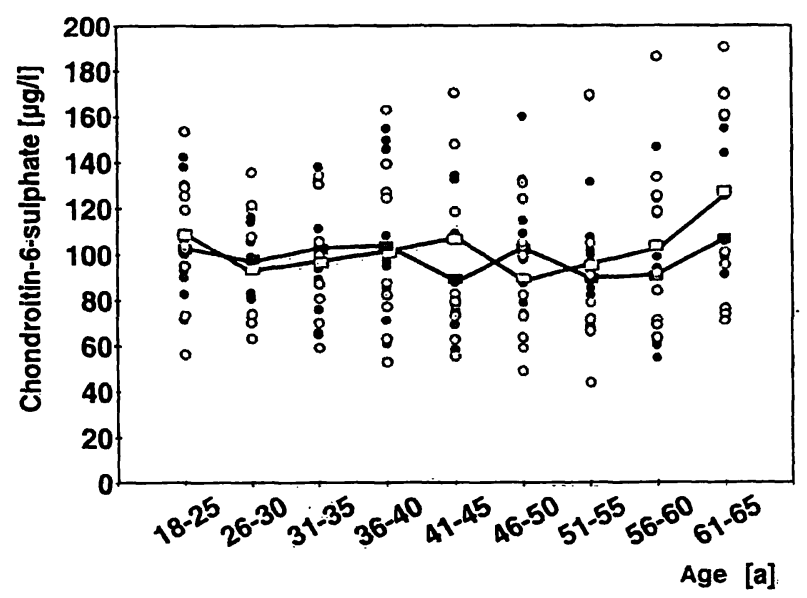

Fig. 5 Chondroitin-6-sulphate concentration in the serum of male $(0)$ and female $(\bullet)$ blood donors of different ages. The means of each age group $(n=10)$ are given for male $(\square-\square)$ and female $(\mathbf{B}-\mathbf{w})$.

Concentration of chondroitin $=6$-sulphate in urine

The urine concentration of chondroitin-6-sulphate in males was $44.5 \pm 21.1 \mathrm{mg} / \mathrm{kg}$ creatinine (mean \pm standard deviation) and in females $53.5 \pm 21.3 \mathrm{mg} / \mathrm{kg}$ creatinine. The chondroitin-6-sulphate clearance in men was determined as $0.41 \pm 0.22 \mathrm{ml} \times \mathrm{min}^{-1}$ and in women as $0.38 \pm 0.15 \mathrm{ml} \times \mathrm{min}^{-1}$. No sex dependence was observed.
Determination of chondroitin-6-sulphate synthesis rate in chondrocyte culture by modification of the enzyme immunoassay

The synthesis of chondroitin-6-sulphate was investigated in the medium of human chondrocytes cultivated with and without agents. The incorporation of ${ }^{14} \mathrm{C}$-labelled galactosamine into chondroitin-6-sulphate was used as a specific index of the synthesis rate. In comparison with chondrocytes incubated without agents, the chondroitin6-sulphate synthesis decreased in the presence of the following agents: tumour necrosis factor $\alpha$ (TNF $\alpha$ ): $64.4 \%$, interleukin- $1 \alpha$ (IL-1 $\alpha$ ): $60.0 \%$, bacterial lipopolysaccharide (LPS): $53.4 \%$, and $\gamma$-interferon $(\gamma$-INF): $21.6 \%$ (tab. 3).

\section{Discussion}

Development of an enzyme immunoassay for chondroitin-6-sulphate was made difficult by the availability of only one monoclonal IgM antibody against chondroitin6-sulphate. We therefore used a competitive method. In our assay, a biotinylated chondroitin-4-sulphate antigen competes with the antigen in the sample for the binding sites of the antibody which was immobilised on the plastic surface of the microtitre plate.

Tab. 3 Measurement of $\left[{ }^{14} \mathrm{C}\right]$ galactosamine incorporation in chondroitin-6-sulphate by modification of the enzyme immunoassay. After the determination of the concentration of chondroitin6-sulphate in the culture medium, the chondroitin-6-sulphate antibody complex was enzymatically detached from the microtitre plates and the radioactivity of the $\left[{ }^{14} \mathrm{C}\right]$ chondroitin-6-sulphate was measured. The calculation of the $\left[{ }^{14} \mathrm{C}\right]$ chondroitin-6-sulphate provides a specific value related to the synthesis rate of this glycosaminoglycan. This is shown in studies with human chondrocyte cultures incubated with different agents for 48 hours. Agent concentrations: interleukin-1 $\alpha$ : $10^{4} \mathrm{U} / \mathrm{l}$; tumour necrosis factor $\alpha$ : 100 $\mu \mathrm{g} / \mathrm{l} ; \gamma$-interferon: $2 \cdot 10^{5} \mathrm{U} / \mathrm{l}$; lipopolysaccharide: $10 \mu \mathrm{g} / \mathrm{l} ;\left[{ }^{14} \mathrm{C}\right] \mathrm{ga}$ lactosamine: $56 \mathrm{MBq} / \mathrm{l}$. Mean and standard deviation of four experiments are given.

\begin{tabular}{llll}
\hline $\begin{array}{l}\text { Incubation } \\
\text { with agents }\end{array}$ & $\begin{array}{l}\text { Immuno- } \\
\text { assays of } \\
\text { chondroitin- } \\
6 \text { 6-sulphate } \\
{[\mu \mathrm{g} / \mathrm{l}]}\end{array}$ & $\begin{array}{l}\text { Radioactivity } \\
\text { of antibody- } \\
\text { bound } \\
\text { chondroitin- } \\
\text { 6-sulphate } \\
{[\mathrm{kBq} / \mathrm{l}]}\end{array}$ & $\begin{array}{l}\text { Specific } \\
\text { incorporation } \\
\text { of }\left[{ }^{14} \mathrm{C}\right] \mathrm{galac}- \\
\text { tosamine } \\
\text { [mmol/kg } \\
\text { chondroitin- } \\
\text { 6-sulphate] }\end{array}$ \\
\hline $\begin{array}{l}\text { Without } \\
\gamma \text {-Interferon }\end{array}$ & $2520 \pm 100 \pm 20$ & $952 \pm 16$ & 252 \\
$\begin{array}{l}\text { Lipopoly- } \\
\text { saccharide }\end{array}$ & $817 \pm 22$ & $190 \pm 5$ & 118 \\
$\begin{array}{l}\text { Interleukin-1 } \alpha \\
\begin{array}{l}\text { Tumour } \\
\text { necrosis } \\
\text { factor } \alpha\end{array}\end{array}$ & $702 \pm 81$ & $136 \pm 9$ & 101 \\
\hline
\end{tabular}


Different procedures were tested to optimise the biotinylation of chondroitin sulphate, since it was observed that the antigenicity of the modified chondroitin-6-sulphate had been altered. The monoclonal anti-chondroitin-6-sulphate antibody recognised the biotinylated chondroitin-6-sulphate to a lesser extent than it did the native form. The decreased antigenicity of biotinylated chondroitin-6-sulphate may be due to steric effects of the sulphate position. In contrast, the antigenicity of biotinylated chondroitin-4-sulphate was unchanged. Consequently, the biotinylated chondroitin-4-sulphate was used as a competitive antigen at a concentration of $100 \mathrm{mg} / \mathrm{l}$ and reproducible dose response curves were obtained for the determination of chondroitin-6-sulphate in body fluids and cell culture media. Our method avoids the use of radiolabelled ligands and, by using enzyme immunoassay plates, has proved itself to be a rapid and efficient technique.

The biochemistry of cartilage destruction in inflammatory and degenerative joint disease has been extensively studied, and it has been found that the loss of proteoglycans of the extracellular matrix is one of the earliest events during the pathobiochemical process $(11-13)$. Thus, the measurement of proteoglycans and their catabolic products in synovial fluid and serum may provide useful diagnostic markers for joint diseases. However, the majority of glycosaminoglycans are ubiquitous intercellular matrix components of different connective tissues. It has been suggested that keratan sulphate is a more specific analyte, since it mainly originates from cartilage and, to a lesser extent, from the cornea and aorta (1). Therefore, antibodies against these glycosaminoglycans were developed and used in several immunological assays. In some studies it has been reported that patients with osteoarthritis showed a significantly higher serum concentration of keratan sulphate than healthy volunteers. However, there is still considerable controversy as to whether the serum concentration of keratan sulphate is a specific indication of cartilage destruction $(8,14-15)$.

Chondroitin-6-sulphate is a glycosaminoglycan, which may also be used as a diagnostic factor in connective tissue diseases, including intracellular degradation of connective tissue and the metabolic activity of connective tissue cells during repair processes. However, the diagnostic relevance of this quantity must be elucidated in further investigations.

The synovial cell culture représents a defined model for obtaining information on the metabolism of chondroitin sulphate in the synovial system and for investigating the influence of different agents on the metabolism of this glycosaminoglycan. In studies on the synthesis of chondroitin sulphate the incorporation of radiolabelled galactosamine into the glycosaminoglycan is usually determined. However, measurement of radiolabelled chondroitin sulphate isolated from cell culture medium may lead to oversimplification of the interpretation, because changes in the measured chondroitin sulphate concentration in the medium can be influenced by partial steps of metabolism, such as intracellular synthesis, secretion into the medium, re-uptake of the macromolecule and intracellular degradation. One unsatisfactory way which has been used to overcome this problem is the simultaneous investigation of the concentration of chondroitin-6-sulphate in the extra-, peri- or intracellular pool (16). The new enzyme immunoassay of chondroitin-6sulphate, in combination with the assay of the antibody bound to ${ }^{14} \mathrm{C}$-labelled chondroitin-6-sulphate, now enables measurement of the specific incorporation of $\left[{ }^{14} \mathrm{C}\right]$ galactosamine into chondroitin-6-sulphate as a means of quantifying the synthesis rate of this glycosaminoglycan. Therefore, amplification of the enzyme immunoassay in this way represents a useful tool for obtaining rapid information on the synthesis of chondroitin-6-sulphate in cell culture (10).

\section{Acknowledgement}

We are grateful to Ms. Regina Schroven and Ms. Anne Kathrin Brunner for their excellent technical assistance, and PD Dr. Imo Scheuer, Kreiskrankenhaus Herford, Germany. This work was supported by the "Deutsehe Forschungsgemeinschaft", Bonn-Bad Godesberg, within the project SFB 223, B 03. In addition we wish to thank Ms. Grainne Delany for linguistic advice.

\section{References}

1. Wight, T. N., Heinegard, D. K. \& Hascall, V. C. (1991) Proteoglycans - Structure and function. In: Cell Biology of Extracellular Matrix, 2nd ed. (Hay, E., ed.) pp. 45-100, Plenum Press, New York.

2. Kimura, J. H., Lohmander, L. S. \& Hascall, V. C. (1984) Studies on the biosynthesis of cartilage proteoglycan in a model system of cultured chondrocytes from the swarm rat chondrosarcoma. J. Cell. Biochem. 26, 261-278.

3. Greiling, H., Stuhlsatz, H. W. \& Tillmanns, U. (1984) Chondroitin, chondroitin-4-sulphate, chondroitin-6-sulphate, and dermatan sulphate. In: Methods of Enzymatic Analysis, Vol VI (Bergmeyer, ed.), pp. 60-69.
4. Gurr, E., Pallach, G., Tamm, C. \& Delbrück, A. (1985) High performance liquid chromatographic àssay of disaccharides and oligosaccharides produced by the digestion of glycosaminoglycanis with chondroitin sulphate lyases. J. Clin. Chem. Clin. Biochem. 23, 77-87.

5. Baker, J. R., Caterson, B. \& Christncr; J. E. (1982) Immunological characterisation of cartilage proteoglycans. Methods of Enzymology 83, 216-235.

6. Caterson, B., Christner, J. E., Baker, J. R. \& Couchman, J. R. (1985). Production and characterisation of monoclonal antibodies directed against connective tissue proteoglycans. Fed. Proc. 44, 386-393. 
7. Kongtawelert, P. \& Gosh, P. (1990) A new sandwich-ELISA method for the determination of keratan sulphate peptides in biological fluids emplyoing a monoclonal antibody and labelled avidin biotin technique. Clin. Chim. Acta 195, 17-26.

8. Alwan, W. H., Carter, S. D., Bennett, D., May, S. A. \& Edwards, G. B. (1990) Cartilage breakdown in equine osteoarthritis: Measurement of keratan sulphate by an ELISA system. Research in Veterinary Science 49, 56-60.

9. Avnur, Z. \& Geiger, B. (1984) Immunocytochemical localisation of native chondroitin sulphate in tissues and cultured cells using specific monoclonal antibody. Cell 38, 811-822.

10. Kähnert, H. \& Kleesiek, K. (1993) Influence of the proteoglycan synthesis of cultured human chondrocytes and synovial cells by different cytokines. Eur. J. Clin. Chem. Clin. Biochem. (in preparation).

11. Alexander, C. M. \& Werb, Z. (1991) Extracellular matrix degeneration. In: Cell Biology of Extracellular Matrix, $2^{\text {nd }}$ ed. (Hay, D. E., ed.), chapter 8, pp. 255-294, Plenum Press, New York.

12. Bayliss, M. T. (1985) Proteoglycan structure in normal and osteoarthrotic human cartilage. In: Articular Cartilage Biochemistry (Kuettner, K. E., Schleyerbach, R. \& Hascall, V. C., eds.), pp. 295-311, Raven Press, New York.

13. Maroudas, A., Katz, E. P., Wachtel, E. J., Mizrahi, J. \& Soundry, M. (1985) Physicochemical properties and functional be- havior of normal and osteoarthrotic human cartilage. In: $A r-$ ticular Cartilage Biochemistry (Kuettner, K. E., Schleyerbach, R. \& Hascall, V. C., eds.), pp. 311-331, Raven Press, New York.

14. Thonar, E. J.-M. A., Lenz, M. E., Klintworth, G. K., Caterson, B., Pachman, L. M., Glickman, P., Katz, R., Huff, J. \& Kucttner, K. E. (1985) Quantification of keratan sulphate in blood as a marker of cartilage catabolism. Arthritis Rheum. $28,1367-1376$.

15. Saxne, T., Heinegard, D. \& Wollheim, F. A. (1987) Cartilage proteoglycans in synovial fluid and serum in patients with inflammatory joint disease. Relation to systemic treatment. Arthritis Rheum. 30, 972-979.

16. Kleesiek, K. \& Greiling, H. (1982) Effect of anti-inflammatory agents on the glycosaminoglycan metabolism in cultured human synovial cells. Rheumatol. Int. 2, 167-174.

Professor Dr. Knut Kleesiek Institut für Laboratoriums- und

Transfusionsmedizin

Herz- und Diabeteszentrum

Nordrhein-Westfalen

Universitätsklinik der Ruhr-Universität Bochum

Georgstraße 11

D-32545 Bad Oeynhausen

Germany 


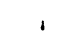

